\title{
A STRATEGY TO ENHANCE POSITIVE WORKING RELATIONSHIPS AMONG THE ROLE PLAYERS WITHIN THE MANAGED HEALTHCARE CONTEXT IN GAUTENG
}

\author{
Shongy Mahlo \\ MCur; RAU Masters student
}

Marie Muller

DCur; Professor of Nursing Science, RAU

\begin{abstract}
The introduction of managed healthcare in South Africa was aimed at the reduction of medical costs, which were increasing at a high rate for the past few years, particularly so in a private healthcare industry. Managed healthcare is a system of healthcare delivery, which ensures that cost effective quality care is provided to patients. A positive working relationship is necessary among the role players in the provision of cost effective quality care within the managed healthcare context. Role players experience problems in the delivery of healthcare, affecting their working relationship, which in turn affects the quality of care provided to patients. Because managed healthcare is a fairly new concept in South Africa, little is known about the problems. As a result, there are no guidelines for the formulation of a strategy to enhance positive working relationships among the role players within the context of managed healthcare. Understanding of the problems experienced by the role players will provide a baseline to the researcher to formulate a strategy to enhance positive working relationships. The overall purpose of the study is to formulate a strategy to enhance a positive working relationship among the role players within the managed healthcare context in Gauteng. The problems experienced by the role players in this regard, as well as suggested solutions to counteract these problems, were presented in a separate article. This is the follow-up article that aims at describing the strategy to enhance a positive working relationship between the role players.
\end{abstract}

A qualitative, exploratory, descriptive and contextual design was followed to answer the research questions. Focus group interviews were conducted to collect data and a content analysis was conducted as described by Tesch (1990), followed by the development of a strategy to enhance a positive working relationship among the role players, based on role player empowerment, staff development, recruitment and selection, use of advanced information technology and standardisation of methods across managed healthcare industry. The researcher employed Lincoln and Guba's (1985:290) principles of trustworthiness and the ethical standards as set by DENOSA (1998) were adhered to by the researcher to facilitate the quality of the study. It was recommended that the strategy be implemented and evaluated for its effectiveness by evaluating the quality of working relationships among the role players and that ethical standards be formulated in managed healthcare.

\section{OPSOMMING}

Bestuurde gesondheidsorg is in Suid-Afrika ingestel om die verhoogde kostes in privaatgesondheidsdienste te bekamp. Bestuurde gesondheidsorg is 'n stelsel van gesondheidsdienslewering om die voorsiening van koste-effektiewe gehaltesorg te verseker. Positiewe werksverhoudinge tussen alle rolspelers is nodig om koste-effektiewe gehaltesorg binne die konteks van bestuurde gesondheidsorg te lewer. Rolspelers ervaar egter probleme in die voorsiening van hierdie gesondheidsorg wat nie net die werksverhouding bë̈vloed nie, maar ook die gehalte van sorg wat aan pasiënte voorsien word. Bestuurde gesondheidsorg is 'n relatiewe nuwe begrip in Suid-Afrika en derhalwe is daar min bekend oor die probleme wat ervaar word, met die gevolg dat daar nie riglyne bestaan vir die ontwikkeling van 
'n strategie om 'n positiewe werksverhouding tussen die rolspelers te bevorder nie. Begrip vir die probleme wat deur rolspelers ervaar word, sal as basis dien vir die formulering van 'n strategie om hierdie werksverhoudinge te verbeter. Die navorser het dus besluit on die probleme wat rolspelers ervaar te verken en te beskryf. Die doel met hierdie studie is om 'n strategie te formuleer vir die bevordering van 'n positiewe werksverhouding tussen rolspelers binne die konteks van bestuurde gesondheidsorg in Gauteng.

'n Kwalitatiewe, verkennende, beskrywende en kontekstuele navorsingsontwerp is nagevolg om die vrae te beantwoord. Fokusgroeponderhoude is gevoer, gevolg deur ' $n$ inhoudsontleding van die data soos beskryf deur Tesch (1990). Dit was gevolg deur die ontwikkeling van 'n strategie om positiewe werksverhoudinge tussen rolspelers te bevorder, wat gebaseer is op die bemagtiging van rolspelers, personeelontwikkeling, personeelwerwing en -keuring, die benutting van gevorderde inligtingstegnologie en die standaardisering van metodes binne die bestuurde gesondheidsorgindustrie. Guba en Lincoln (1985:290) se beginsels van vertrouenswaardigheid is nagevolg en die navorser het die etiese standaarde, soos voorgestel deur DENOSA (1998), nagekom om die gehalte van die navorsing te fasiliteer. Daar word aanbeveel dat hierdie strategie gë̈mplementeer en beoordeel word deur die evaluering van die gehalte van werksverhoudinge tussen die rolspelers in bestuurde gesondheidsorg. Die formulering van etiese standaarde binne bestuurde gesondheidsorg word ook aanbeveel.

\section{INTRODUCTION}

Managed healthcare is a system of healthcare delivery which is aimed at ensuring that cost effective quality healthcare is provided to patients, who are members of medical aid schemes within the context of managed healthcare. Various role players are involved in the delivery of healthcare within the managed healthcare context. According to Anderson (HASA, 1998:170), there are three main role players namely, the service provider, the funder and the member. For the purpose of this study, the member was excluded and role players consisted of the service providers and funders. Service providers are represented by the private hospitals and doctors, and funders are represented by managed care organisations. Private hospitals are represented by the nursing service manager, responsible for ensuring that quality care is provided in a cost effective manner in a nursing service, the unit manager, responsible for ensuring that cost effective quality care is provided in a medical unit, and the hospital case manager who liase with the managed care organisations and ensuring that the hospital gets paid for the services rendered. Managed care organisations are represented by the managed care case managers, responsible for monitoring the quality of care provided to their members by the service providers and authorising payment for such services. Problems experienced by the role players are related to com- munication, staff competence, cost saving versus quality care, procedural complexity, perceived loss of power by doctors and patients and accounts payment. These problems have a negative effect on the working relationships between the different role players, which could in turn affect the quality of care provided to patients. The relevant research questions are as follows:

- What are the problems experienced by the role players within the managed healthcare context in Gauteng, and what are the recommended solutions to counteract these problems?

- What strategy can be formulated to enhance positive working relationship among the role players within the managed healthcare context in Gauteng?

The aim of the study is to formulate a strategy to enhance positive working relationship among the role players within the managed healthcare context in Gauteng. The specific objective is to explore and describe the problems experienced by the role players within the managed healthcare context in Gauteng and their suggested solutions. The results of the study are used for the development of a strategy to enhance a positive working relationship and the strategy relates to role player empowerment, staff development, standardisation of methods across managed healthcare industry, recruitment and selection, as well as the use of advanced information technology. 


\section{TERMINOLOGY}

\section{Managed healthcare}

Managed healthcare is a system of healthcare delivery that influences the utilisation of health services and the cost of these services resulting in performance measurement (Veliotes, Magennis and Brown, 1993:37).

\section{Role players}

A role player refers to the professional service providers and funders within the managed healthcare context in Gauteng.

\section{Professional service providers}

Professional service providers refer to private hospitals and general medical practitioners within the managed healthcare context in Gauteng.

\section{Funders}

Funders are medical aid schemes, a form of medical insurance that pay for the services received by the members from a practitioner of their choice (MASA, 1993:16), within the managed healthcare context in Gauteng.

\section{Quality care}

Quality care refers to the compliance to pre-determined standards in relation to healthcare delivery within the managed health care context.

\section{Working relationship}

Working relationship refers to a positive interpersonal working relationship among the role players during service delivery within the context of managed healthcare in Gauteng.

\section{Problems}

Refers to the negative experiences by the role players within the context of managed healthcare during the delivery of healthcare in Gauteng, which affect their working relationship in the delivery of healthcare.

\section{Strategy}

A strategy refers to the written guidelines/standards to enhance a positive working relationship among the role players within the managed healthcare context in Gauteng.

\section{RESEARCH DESIGN}

A qualitative, exploratory, descriptive and contextual design was conducted with selected private hospitals, managed care organisations and general medical practitioners in Gauteng. Focus group interviews were conducted with the nursing service managers, unit managers of medical wards and hospital case managers from three private hospitals, three case managers representing managed care organisations each and four general medical practitioners. A purposive and convenient sampling was used in the selection of the participants qualified to participate in accordance with the set inclusion criteria which relates to the following:

- Private hospital with a medical ward, nursing service manager and a hospital case manager.

- Nursing service manager with at least one year of experience as a nursing service manager in a private hospital.

- Medical ward unit manager with at least one year of experience as a unit manager in a medical ward in a private hospital.

- Hospital case manager with at least one year of experience as a hospital case manager.

- Managed care case manager with at least one year of experience as a case manager in a managed care organisation.

- General medical practitioner involved in providing private healthcare services within the managed healthcare context for at least one year.

- Managed care organisations must be in existence at least for a year.

The researcher used focus group interviews for data collection as it encourages interaction between the group members (Krueger, 1988). This in turn enabled the researcher to do an in depth exploration of the problems 


\section{TERMINOLOGY}

\section{Managed healthcare}

Managed healthcare is a system of healthcare delivery that influences the utilisation of health services and the cost of these services resulting in performance measurement (Veliotes, Magennis and Brown, 1993:37).

\section{Role players}

A role player refers to the professional service providers and funders within the managed healthcare context in Gauteng.

\section{Professional service providers}

Professional service providers refer to private hospitals and general medical practitioners within the managed healthcare context in Gauteng.

\section{Funders}

Funders are medical aid schemes, a form of medical insurance that pay for the services received by the members from a practitioner of their choice (MASA, 1993:16), within the managed healthcare context in Gauteng.

\section{Quality care}

Quality care refers to the compliance to pre-determined standards in relation to healthcare delivery within the managed health care context.

\section{Working relationship}

Working relationship refers to a positive interpersonal working relationship among the role players during service delivery within the context of managed healthcare in Gauteng.

\section{Problems}

Refers to the negative experiences by the role players within the context of managed healthcare during the delivery of healthcare in Gauteng, which affect their working relationship in the delivery of healthcare.

\section{Strategy}

A strategy refers to the written guidelines/standards to enhance a positive working relationship among the role players within the managed healthcare context in Gauteng.

\section{RESEARCH DESIGN}

A qualitative, exploratory, descriptive and contextual design was conducted with selected private hospitals, managed care organisations and general medical practitioners in Gauteng. Focus group interviews were conducted with the nursing service managers, unit managers of medical wards and hospital case managers from three private hospitals, three case managers representing managed care organisations each and four general medical practitioners. A purposive and convenient sampling was used in the selection of the participants qualified to participate in accordance with the set inclusion criteria which relates to the following:

- Private hospital with a medical ward, nursing service manager and a hospital case manager.

- Nursing service manager with at least one year of experience as a nursing service manager in a private hospital.

- Medical ward unit manager with at least one year of experience as a unit manager in a medical ward in a private hospital.

- Hospital case manager with at least one year of experience as a hospital case manager.

- Managed care case manager with at least one year of experience as a case manager in a managed care organisation.

- General medical practitioner involved in providing private healthcare services within the managed healthcare context for at least one year.

- Managed care organisations must be in existence at least for a year.

The researcher used focus group interviews for data collection as it encourages interaction between the group members (Krueger, 1988). This in turn enabled the researcher to do an in depth exploration of the problems 
experienced by the role players. Focus group interviews were conducted based on the principles discussed by Krueger (1988), making provision for the following:

- Only information rich participants who were willing to participate were selected.

- The researcher used a group small enough to allow every group member to participate and big enough to generate information.

- Although they had common background, all group members were not familiar with each other, as this could influence the information they generate.

- To ensure that people attend focus group interviews, transport and snacks were provided.

- Interviews were conducted in a series to ensure that all participants have a chance to speak.

The following questions were asked during the focus group interviews: what problems do you experience within the context of managed health care and what solutions do you suggest to counteract these problems?

Interviews were video recorded with the permission of all participants. Information was confirmed with the participants in a follow-up session. The appropriate code was written on each cassette and was locked at the researcher's home in a steel cabinet. Comprehensive field notes were written by the researcher to capture external factors that might have influence on the results and the experiences of the researcher. Content analysis as described by Tesch (1990) was applied to analyse the data. The principles of trustworthiness as described by Lincoln and Guba (1985:290) which relate to credibility, confirmability, dependability, and transferability were applied by the researcher to cnsure the trustworthiness of the study:

- To avoid making own interpretations, especially because the researcher is involved in the industry, member checking was conducted, where the participants were asked to confirm the veracity of the statements in the third focus group, which was designed for a follow-up session.

Although four focus group interviews were conducted, the same professional facilitator and questions were used to maintain consistency throughout the research process.

All the diskettes, together with the transcriptions were given to the University for storage in the archives as a way of enhancing the credibility of the findings through referential adequacy.

- Sufficient audit trail will be kept for later critiques and evaluation.

- Each focus group discussion was preceded by an informal discussion in an attempt to "break the ice" and hopefully build the relationship of trust.

- The results were exposed to a literature control and an international data triangulation during a visit to the USA by the researcher.

- The researcher employed a professional facilitator as the researcher is not experienced in conducting focus groups and because of the sensitive nature of the topic.

- To facilitate the quality of the study, the researcher adhered to the ethical standards set by DENOSA (1998).

\section{RESULTS}

The sample realisation is presented, followed by a summary of the problems experienced by the role players. A strategy to enhance a positive working relationship between the different role players is finally presented.

\section{Sample realisation}

TABLE 1: SAMPLE REALISATION, ANALYSIS OF PARTICIPANTS

\begin{tabular}{|l|l|l|c|}
\hline $\begin{array}{c}\text { Focus Group } \\
\text { Number }\end{array}$ & Category & $\begin{array}{c}\text { Number of } \\
\text { organisations } \\
\text { represented }\end{array}$ & $\begin{array}{c}\text { Number of } \\
\text { participants }\end{array}$ \\
\hline 1 & Private Hospitals & 3 & 9 \\
\hline 2 & $\begin{array}{c}\text { Managed Care } \\
\text { organisations }\end{array}$ & 3 & 3 \\
\hline $\begin{array}{c}\text { Private Hospitals } \\
\text { and Managed Care } \\
\text { Organisations }\end{array}$ & 6 & 12 \\
\hline 4 & $\begin{array}{c}\text { General medical } \\
\text { practitioners }\end{array}$ & 4 & 4 \\
\hline
\end{tabular}


Four focus group interviews were conducted in the study. The first focus group interview composed of three private hospitals represented by the nursing service manager, medical ward unit manager and the hospital case manger with a total of nine participants. The second focus group composed of three managed care organisations, each represented by a case manager $(n=3)$, the third focus group combined private hospitals and managed care organisations $(n=12)$ and the fourth one consisted of four general medical practitioners (see table one).

\section{Problems experienced by the role players}

Problems experienced by the role players within the context of managed healthcare in Gauteng are related to communication, inadequate staff competence, procedural complexity, cost saving versus quality care, perceived loss of power by doctors and patients and the system of accounts payment.

\section{Communication}

Communication problems are grouped into information flow and poor relationships. Managed care organisations $(n=3)$, private hospitals ( $n=9)$ and general medical practitioners $(n=4)$ are experiencing difficulties in obtaining information from each other to review the conditions of patients and for the managed care organisations to authorise payment of services provided to patients who are their members. Doctors refuse to provide necessary information required by managed care organisations to hospital case managers to authorise payment of services provided to patients. As a result, managed care case managers refuse to update the accounts or authorise payment of services provided. Two hospital case managers raised this problem. Managed care organisations do not educate their members on the requirements of managed healthcare. As a result, patients go to hospitals for admissions without knowing what they are admitted for and without authorisation numbers from their managed care organisations. Hospitals experience frustrations because they find themselves in situations where they have to phone doctors to find out patients' admission diagnosis and the managed care organisations concerned for the authorisation numbers. One case manager confirmed this problem. Doctors refuse to provide necessary information to managed care case managers to update conditions of patients as they perceive managed healthcare as being implemented by managed care organisations to make money at their expense. Two managed care case managers emphasised the problem. Doctors and private hospitals are not open to information on managed healthcare because of their resistance to change and they see managed healthcare as interfering with their relationships with their patients and this problem was stressed by one respondent. Doctors also refuse to talk to case managers because they are just nurses and they would prefer to talk to other doctors regarding the treatment of their patients. One participant articulated the problem. Managed care case managers $(n=3)$ are also experiencing a problem with doctors providing insufficient or incorrect information on the conditions and treatment of patients because they think managed care organisations will pay for the services that they normally don't pay for. One managed care case managers corroborated the problem. Doctors find themselves in a situation of educating patients on the rules of their managed care organisations and expectations on managed healthcare rather than treating them, because of the lack of member education from managed care organisations. Two participants articulated the problem. Doctors are experiencing frustrations of not being informed on their roles and expectations of managed healthcare by managed care organisations, yet they are expected to comply with the rules being followed by managed care organisations. Two participants emphasised this problem. Managed care organisations $(n=3)$ experience problems in that doctors do not inform patients on what they are being admitted for when they send them to hospitals for admissions, and as a result, patients phone for authorisation numbers without knowing what they are going to be admitted for. Two participants emphasised the problem. The following selected direct quotations are used to emphasise the information related problems as experienced by the role players: 
" Doctors don't want to give us information required by these eh...managed healthcare people, and in this case, managed care organisations don't want to update our accounts if they don't get this information"

"You find patients coming to hospital without knowing what they are getting admitted for and without authorisation numbers..."

"You can give information and education to people, but if they are not willing, if they shut to it, you have an extra barrier to overcome. So I think there are doctors and hospitals that understand it, but are not accepting it because they perceive it as undermining their decisionmaking process and relationship with their patients..."

"Patients phone for authorisation numbers without knowing what they are getting admitted for"

"...I mean giving us insufficient information, this is frustrating and they also give us incorrect information..., because they think we will pay for something that we normally don't pay for"

"The most serious problem is that they are busy dictating to us, but they are failing to educate their members"

"Refusing to pay the account because I did not submit the account according to their expectations, yet they did not even inform us about such expectations"

These problems are confirmed by HASA (1999:10;27). Building meaningful relationship is also difficult for both private hospitals and managed care organisations because of the lack of specific reliable contacts. The following direct quotations corroborated the problem:

"Another problem is making contact with necessary people at managed care organisations"

"You build relationship with one person, when you try to get back to this person that you have build nice relationship with, you find that she has been transferred to another department"

"You also find that there are no reliable people to talk to for updates, because some hospitals still don't have case managers you know"

TABLE 2: SUMMARY OF INFORMATION-RELATED PROBLEMS

\begin{tabular}{|c|c|c|}
\hline Hospltals & Managod care organisation & Doctors \\
\hline 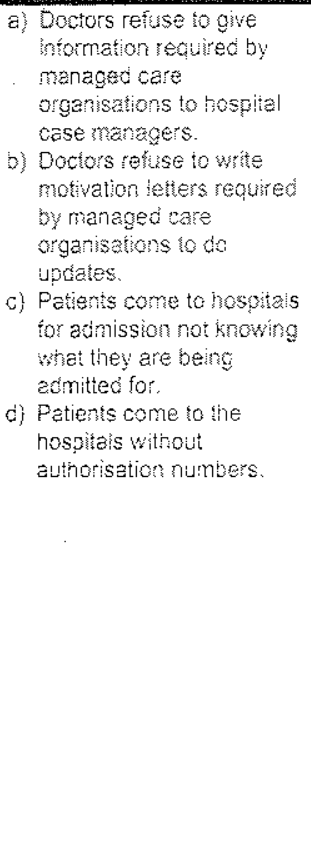 & $\begin{array}{l}\text { a) Dociors refuse to give } \\
\text { necessary information to } \\
\text { managed care case } \\
\text { managers to co updates. } \\
\text { b) Doctors and hospitais do } \\
\text { not accept information on } \\
\text { managed healthcare } \\
\text { because of their resistance } \\
\text { to change. } \\
\text { Doctors refuse to talk to } \\
\text { care case managers } \\
\text { because they are nurses } \\
\text { and prefer to talk to } \\
\text { coctors. } \\
\text { d) Patients phone managed } \\
\text { care organisations for } \\
\text { authorisation numbers } \\
\text { without necessary } \\
\text { information to grant sucis } \\
\text { authorisation. } \\
\text { e) Doctors sometimes provide } \\
\text { insufticient or incorrect } \\
\text { information regarding the } \\
\text { diagnosis or treatment of } \\
\text { the patient. } \\
\text { When phoning the } \\
\text { hospitals, there is aways } \\
\text { insuficient information for } \\
\text { managed care case } \\
\text { managers to do updates. }\end{array}$ & $\begin{array}{l}\text { a) Lack of iniomation fiom } \\
\text { manageo care } \\
\text { orgatisations to the } \\
\text { patients on managed } \\
\text { heaiticare. } \\
\text { b) There is no intomation } \\
\text { flow from managed care } \\
\text { organisations to service } \\
\text { proviers }\end{array}$ \\
\hline
\end{tabular}

\section{Staff competence}

Both professional service providers and the funders resent talking to people with limited or no medical training, which makes it difficult to update conditions of patients. The following selected quotations confirm the problem:

"People that we talk to on the other side of medical aids don't have necessary medical knowledge to understand the information that they request"

"What about talking to the hospital confirmation clerks with those hospitals who don't have case mangers"

"And... also dictating to us as to how to operate, meanwhile these dictators don't even have medical knowledge"

This problem is supported by HASA (1999:100: "Why 
should a nursing sister be allowed to challenge the opinion of a surgeon that an operation is not necessary?"

"From managed care organisation's side, protocols are a problem, protocols as opposed to what we are doing at the hospitals"

"Rules differ from managed care organisation to managed care organisation, it is so amusing because they expect us to adhere to all these rules"

\section{Procedural complexity}

The main problem is that the procedures followed by managed care organisations are being perceived by the hospitals ( $\mathrm{n}=9$ ) as complex and rigid, and are often not known to them, leading to frustration and resentment. This appears to be a manifestation of a lack of standardisation across managed healthcare industry. There is too much reliance on the protocols by managed care organisations without due considerations. This is also confirmed by HASA (1999:49): "How can a protocol distinguish whether a headache needs an aspirin or whether it is related to a tumor?"

\section{Cost saving versus quality care}

Role players are experiencing a dilemma in balancing the provision of quality care on the one hand, with the cost of providing care to the member. Private hospitals $(n=9)$ feel that the quality of care provided to patients is being compromised because managed care organisations are desperate to save costs and make profit. Three participants confirmed the problem. Managed care case managers ( $n=3$ ) experience a problem of being expected to prove their existence to their organisations by saving costs. Three participants confirmed the problem. Patients also get admitted to hospitals for planned admissions without informing their managed care organisations, which make it difficult for managed care case managers to save cost by stopping unnecessary admissions $(n=3)$, the following quotations emphasise the problem:

"Another thing is that medical aids are desperate to save cost rather than the quality of care provided to patients"

"When you are in managed care organisations, you prove your existence that you make a difference in an organisation by saving cost"

"Another problem is the pre-authorisation... We still get a lot of pre-authorisation requests when patients are being at the door being admitted, or even retrospectively. In this way you cannot make an impact on the savings"

\section{Perceived loss of power by doctors and patients}

Doctors feel that managed care organisations are taking over their power to decide how and where the patient must be treated and also dictating to patients as to who and where they must be treated. The following selected direct quotations confirm the problem:

"Another problem we are facing is that these managed care organisations are dictating to doctors and patients as to which hospitals to be used"

"I think these managed care organisations want to employ us and be in control of us"

\section{Accounts payment}

Doctors feel that managed care organisations demand quality care to their members, but they don't want to pay for it. This was stressed by the following quotations from the transcriptions by four participants:

"Accounts are not paid in time or not paid at all. This is frustrating as they expect us to provide quality care, yet they don't want to pay for this quality care which they demand from us"

"I think they look for a good reason for not paying the accounts"

These problems are confirmed by HASA (1999:27; 49). The lack of education in managed healthcare is also supported by Gallaway and Lee (1997:23) and by TWIG Inform (1998:12).

\section{International data triangulation}

International data triangulation indicates that the USA also experienced problems in the implementation of 
managed healthcare and these problems are not discussed in this article as the focus of this article is on the problems experienced by the role players in Gauteng and the strategy to enhance positive working relationship among them. All problems identified in the USA confirmed problems identified by the focus group interviews in Gauteng.

Not all role players experienced all the problems. Similarly, some problems were experienced by more than one role player. Table three is a summary of all problems as experienced by different role players.

TABLE 3: SUMMARY OF PROBLEMS EXPERIENCED BY DIFFERENT ROLE PLAYERS

(X represents the problem being experienced by the different role players)

\begin{tabular}{l|lll}
\hline Problem & Hospitals & Managed care organisations & Doctors \\
\hline Communication & $x$ & $x$ & $x$ \\
- Information & $x$ & $x$ & $x$ \\
- Poor relationship & $x$ & $x$ & $x$ \\
Staff competence & $x$ & $x$ & \\
Cost saving versus quality care & $x$ & & \\
Procedural compiexity & $x$ & & \\
Perceived loss of power by doctors and & $x$ & & \\
patienis & & & \\
Account payment & & \\
\hline
\end{tabular}

\section{Suggested solutions}

Solutions suggested by the role players to counteract identified problems revolved around the standardisation of methods, procedures and systems across managed healthcare industry, involvement of all role players in the formulation of guidelines and standards, education of role players on managed healthcare, recruitment and employment of medically qualified people and member education. All role players are of the opinion that standardisation of managed healthcare principles by all managed care organisations across the managed healthcare industry will eliminate most of the problems related to information flow as it will be easy for the service providers to follow these principles. Role play- ers are also of the opinion that involvement of all role players by managed care organisations in standards and guidelines formulation in managed healthcare will enhance the acceptance of managed healthcare by the professional service providers. All role players see the employment of medically qualified people as case managers by both managed care organisations and private hospitals as going to resolve the problems of inadequate staff competence and information flow. Role players also see member education by their managed care organisations as another strategy to enhance information flow among the role players. It was also suggested by all role players that role player education on managed healthcare by the managed care organisations will resolve a lot of communication problems as all role players will be aware of their roles and expectations in the context of managed healthcare. Doctors are of an opinion of the formation of the independent practitioners' associations for peer review and to fight managed care organisations as a group of their unfair expectations from them.

International data triangulation indicates that the USA role players used a combination of the identified solutions in the focus group interviews to resolve their problems.

\section{A STRATEGY TO ENHANCE POSITIVE WORK- ING RELATIONSHIP AMONG THE ROLE PLAY - ERS}

A strategy to enhance positive working relationship among the role players within the managed healthcare context in Gauteng is described in the introduction, context, purpose and guidelines.

\section{Introduction}

Managed healthcare is the control of cost in healthcare delivery without jeopardising quality of care provided to patients. It is a system of healthcare delivery that ensures cost effective quality care to patients. Various role players are involved in managed healthcare. Various problems identified in focus group interviews are expe- 
rienced by the role players during healthcare delivery, which have a negative effect on their working relationship, which in turn affect the cost-effective quality of care provided to the patient. A strategy to enhance positive working relationship among the role players was formulated, based on the research results and the relevant literature control. A visual presentation on the conceptual framework of the strategy to enhance positive working relationship among the role players in the context of managed healthcare is provided in figure one. According to Anderson in HASA (1998:170), there are three main role players involved in managed healthcare. Table four summarises three main role players and their responsibilities.

\section{TABLE 4: ROLE PLAYERS AND THEIR RESPONSI- BILITIES}

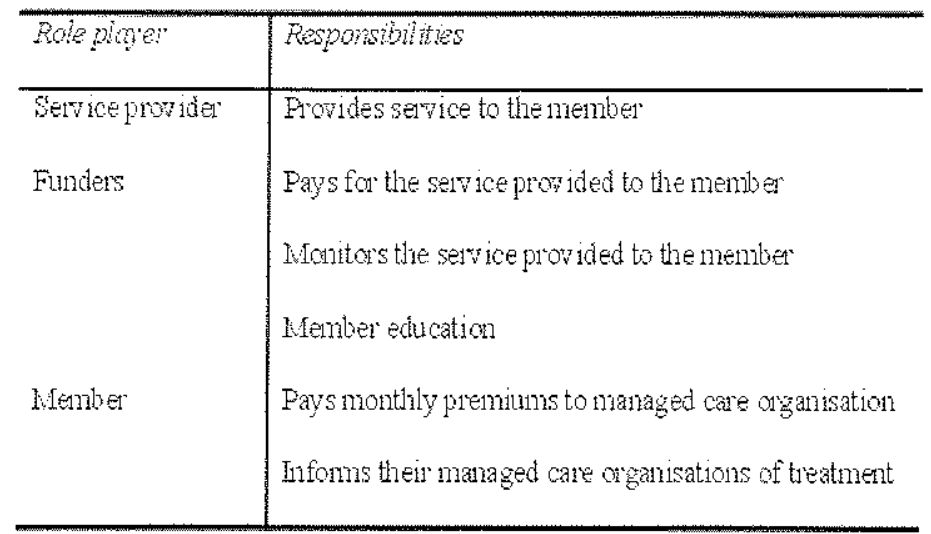

\section{Context}

The context of the strategy is within the private hospitals, managed care organisations and doctors providing private medical services. All these role players are practicing in Gauteng.

\section{Purpose}

The purpose of the strategy is to enhance positive working relationship among the role players within the managed healthcare context in Gauteng, so as to improve the quality of care provided by implementing a strategy for resolving all identified problems, which relates to inadequate communication, inadequate staff competence, cost saving versus quality care, procedural complexity, perceived loss of power by the doctors and patients and account payment.

\section{Guidelines to enhance positive working relation- ship among the role players}

A strategy for enhancing positive working relationship among the role players consist of five strategic themes, namely, empowerment of the role players, staff development, standardisation, use of advanced information technology, and recruitment and selection. The strategy is based on the research results and relevant literature conducted. Each strategic theme resolve specific problems experienced by the role players as will be discussed.

\section{Empowerment of the role players}

Managed care organisations must invite all role players to clarify the concept of managed healthcare, as it is a relatively new concept in South Africa. Expectations from different role players in the delivery of healthcare can be discussed, as well as ideas and guidelines on the protocols being followed can be exchanged among the role players. This strategic theme resolves problems related to communication, account payment, procedural complexity, perceived loss of power by doctors and patients and the conflict between cost saving and quality care.

\section{Staff development}

To ensure that case managers remain clinically knowledgeable and competent, in-service training on case management should be provided to case managers on a regular basis. Both private hospitals and managed care organisations are to organise in-service training programmes to update case managers on efficient case management. A problem of inadequate staff competence is resolved by this strategic theme.

\section{Greater use of information technology}

By making the greater use of information technology by all role players, e.g. extranet and the timelines, accuracy and reliability of information will be enhanced. Role players can share patients' data, role book and other reference sources. Problems related to account payment 
and information flow could be addressed by this strategic theme.

\section{Standardisation of industry processes}

Managed care organisations should standardise their methods, systems, protocols and guidelines, which will resolve problems related to information flow, account payment, cost saving versus quality care, procedural complexity and enhance positive working relationship among the role players, as it will be easy for them to adhere to the same rules from all managed care organisations across the industry.

\section{Staff recruitment and selection}

Managed care organisations and private hospitals should develop a new recruitment and selection instrument in order to ensure that clinically qualified case managers are employed. Table five summarises problems resolved by the strategic themes to enhance positive working relationship among the role players within the context of managed healthcare. This in turn has the positive impact on the cost-effective quality care provided to the patient as depicted in figure one.

\section{TABLE 5: SUMMARY OF PROBLEMS AS RESOLVED BY THE STRATEGIC THEMES.}

\begin{tabular}{|c|c|c|c|c|c|}
\hline & & Strategic & hemes & & \\
\hline Problern addressed & $\begin{array}{l}\text { Staff } \\
\text { Develop } \\
\text { ment }\end{array}$ & $\begin{array}{l}\text { Information } \\
\text { Technology }\end{array}$ & $\begin{array}{l}\text { Role } \\
\text { player } \\
\text { empower } \\
\text { ment }\end{array}$ & $\begin{array}{l}\text { Standar- } \\
\text { disation }\end{array}$ & $\begin{array}{l}\text { Staff } \\
\text { recruitment and } \\
\text { selection }\end{array}$ \\
\hline Communication & & & & & \\
\hline - Information flow & & $x$ & $x$ & $x$ & \\
\hline - Poor relationships & & & $x$ & & \\
\hline Account payment & & $x$ & $x$ & $x$ & \\
\hline Staff Competence & $x$ & & & & $x$ \\
\hline Procedural complexity & & $x$ & $x$ & $x$ & \\
\hline $\begin{array}{l}\text { Perceived loss of power } \\
\text { by doctors and patients }\end{array}$ & & & $x$ & & \\
\hline $\begin{array}{l}\text { Cost saving versus } \\
\text { quality care }\end{array}$ & & & & $x$ & \\
\hline
\end{tabular}

FIGURE 1: CONCEPTUAL FRAMEWORK

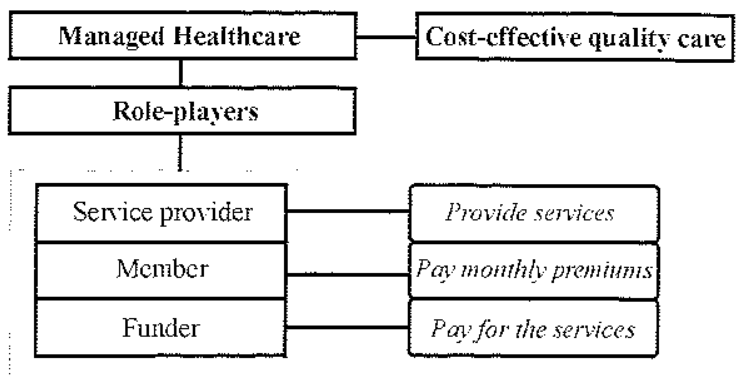

PROBLEMS EXPERIENCED

Communication; Account payment, cost saving/quality, procedural complexity, loss of power, staff competence

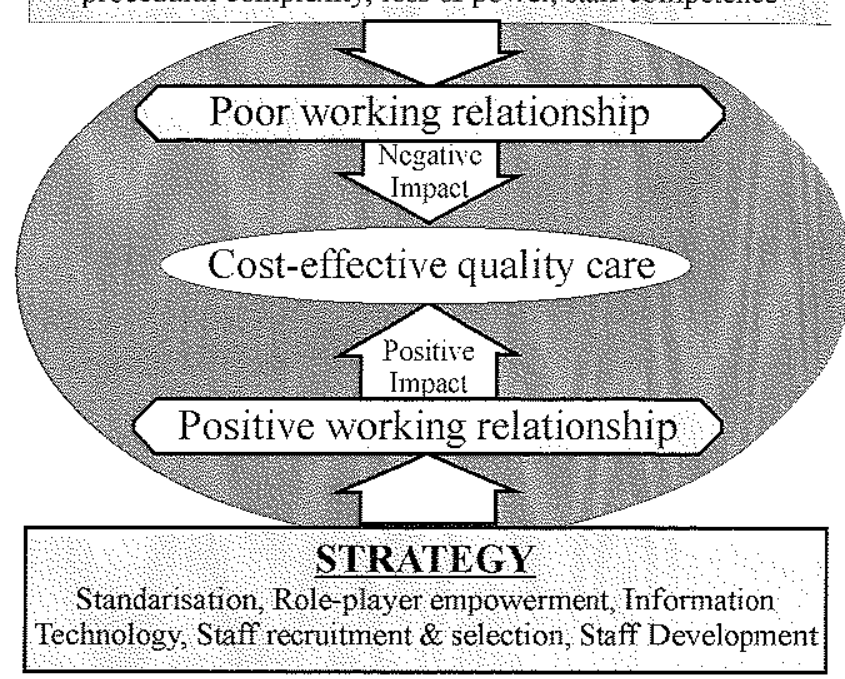

\section{CONCLUSIONS AND RECOMMENDATIONS}

The following conclusions are made:

Problems experienced by the role players within the managed healthcare context in Gauteng were related to communication, staff competence, cost saving versus quality care, procedural complexity, perceived loss of power by doctors and patients and accounts payment.

Communication problems relate to difficulty in the flow of information among the role players and difficulty in building meaningful relationships.

All role players experience a problem of talking to people with limited or no medical knowledge from the other two.

Managed care case managers need to prove their existence to their organisations by saving costs and as a result, the care provided to patients is compromised.

Managed care organisations expect other role players to work according to their procedures rather than what is best for the patients. 
- Managed care organisations dictate to other role players.

- Managed care organisations don't pay the doctors' accounts in time or they don't pay them at all.

All role players suggested solutions to counteract the problems and solutions revolved around the standardisation of managed healthcare methods, role player involvement in standards and guidelines formulation, and formation of independent practitioners' associations by doctors.

From the identified problems and suggested solutions the following recommendations are made:

- The strategy should be implemented and evaluated for its effectiveness by evaluating the quality of the working relationship among the role players in Gauteng.

- Ethical standards should be formulated in managed healthcare, in healthcare delivery.

- Replication studies should be conducted in other provinces in South Africa to confirm the findings.

- Problems experienced by patients in managed healthcare should be explored.

- The following hypotheses are stated for testing:

a) A positive working relationship among the role players within the managed healthcare context improves the quality of care provided to patients.

b) There is a relationship between the quality of the working relationship among the role players in managed healthcare and the quality of care provided to patients.

c) Problems experienced by the role players within the managed healthcare context in the delivery of healthcare have a negative effect on their working relationship.

\section{LIMITATIONS}

The sensitive nature of the topic could have influenced the process and the content of data collection. Participants were interviewed in different venues, which could have influenced the nature of the results. The professional facilitator did not probe enough information from the participants, which could also have influenced the nature of the results.

\section{CONCLUDING REMARKS}

Problems experienced by the role players within the context of managed healthcare have a negative effect on their relationship, which in turn affect the quality of care provided to patients. As managed healthcare is a new concept in South Africa, little was known about the problems. Exploration and description of such problems led to their better understanding and the research results were used as guidelines for the formulation of the strategy to enhance positive working relationship among the role players within the managed healthcare context in Gauteng.

\section{Acknowledgements}

All participants are hereby acknowledged and thanked for their contributions, and who, regardless of the sensitivity of the topic, were willing to participate.

\section{REFERENCES}

BARR, D 1997: Structuring Managed Care Delivery Systems to increase primary care quality. Abstract Book Association for Services Research, 14:3-4.

DE VOS, AS (Editor) 1998: Research at grass roots: A primer for the caring professions. Pretoria: Van Schaik.

DENOSA 1998: Ethical standards for nursing research. Pretoria: DENOSA.

DISCOVERY HEALTH INTERNAL RECORDS 1998: Managed care organisations in Gauteng.

GALLAWAY, SJ \& LEE, B 1997: Parish nursing. Opportunities in community health. Journal of home care, 2(5):244-249.

HASA 1998: Private Health Care; Seventh annual publication. Greenside. Wilbury \& Claymore. 
HASA 1999: Private Healthcare; Eighth annual publication. Greenside: Wilbury \& Claymore.

INGERSOLL, GL; SPITZER, R \& COOK, J 1999: Managed-care research, Part 1: Researching the domain. The Journal of Nursing Administration, 29(11):9-12.

INGERSOLL, GL; SPITZER, R \& COOK, J 1999: Managed-care research, Part 2: Researching the domain. The Journal of Nursing Administration, 29(12):1015.

KONGDVEDT, PR (Editor) 1989: The managed healthcare handbook; New York: Aspen.

KRUEGER, RA 1988: Focus groups: a practical guide for applied research. Newbury Park: Sage Publications.

LEEDY, PD 1993: Practical research: Planning and design; Fifth edition. New York: Macmillan.

LINCOLN, YS \& GUBA, E 1985: Naturalistic inquiry. London: Sage.

MULLAHY, CM 1995: The case manager's handbook. New York: Aspen.

TESCH, R 1990: Qualitative research; analysis, types of software tools. New York: Palmer Press.

TWIG INFORM 1998: Managed care in South Africa today; (Unpublished study).

UNITED HEALTHCARE CORPORATION COMMUNICATIONS 1998: The Language of Managed Healthcare. Minentoka: UHC.

VELIOTES, G; MAGENNIS, R \& BROWN, M 1993: Introduction of managed healthcare in South Africa. Pretoria: State Press. 